\title{
Antibacterial and in vitro Anticancer Study of Methanol Extracts of Clitoria ternatea Leaves
}

\author{
Arunava Das*, G. Shanmuga Priya, S. Soundariya, P. Deepesh, Aileen Rose Edwin, \\ E. Vihashinee, A. Rubiga, S. Megavarthini, R. Eswaran and J. Bindhu \\ Molecular Diagnostics \& Biomolecule Characterization Lab, Department of Biotechnology, \\ Bannari Amman Institute of Technology, Sathyamangalam - 638401, Erode, Tamil Nadu, \\ India; arunavadas@bitsathy.ac.in
}

\begin{abstract}
Clitoria ternatea is often known as butterfly pea plant by the natives and is one of the major plants used in Ayurveda and traditional medicine worldwide. It is also used in food and cosmetic industries for various purposes. In this study, methanol leaf extract of Clitoria ternatea was studied for its antibacterial and in vitro anticancer study against human promyelocytic leukemia cells (HL60). Secondary metabolites like alkaloids, phlobatannin, triterpenoids, flavonoids, lipids, steroids, terpenoids, tannins and glycosides are identified in the extract by phytochemical screening. Leaf extract showed the presence of ethers and carboxylic acid groups (GCMS analysis). The leaf extract showed resistance against Salmonella typhi. Thus, from this study it can be concluded Clitoria ternatea leaves methanol extract has bioactive compounds showing anticancer activity against HL60 cells.
\end{abstract}

Keywords: Antibacterial Activity, Anticancer Activity, Clitoria ternatea, GC-MS Analysis, Phytochemical Screening, MTT Assay

\section{Introduction}

Clitoria ternatea (Fabaceae) is known as Butterfly pea, Asian pigeon wings, blue bellvine, cordofan pea and Shankpushpi. It is predominantly found in tropical equatorial area, a perennial twinning leguminous herb. The length of the plant can vary from $0.5 \mathrm{~m}$ to $3 \mathrm{~m}$. The plants have 5 to 7 leaflets with pinnated leaves. The length of the petioles ranges from $1.5 \mathrm{~cm}$ to 3 $\mathrm{cm}$. They have a persistent stipule which is narrowly triangular with $1 \mathrm{~mm}$ to $6 \mathrm{~mm}$ length and are subulate with predominantly 3 nerved. Filiformed stipules are $2 \mathrm{~mm}$ long and shows characteristic elliptical leaflets. Clitoria ternatea a perennial climber with white or blue coloured flowers ${ }^{11}$. The leaves are both elliptic and obtuse in nature. Being a vine or creeper, it naturally grows well in neutral and moist soil. The fruit from these plants are usually 5 to $7 \mathrm{~cm}$ long and possess 6 to 10 seeds within each flat pod. The tender nature of the fruit makes it an edible fruit ${ }^{2}$. The flowers are axillary and solitary.

The leaf extract of Clitoria ternatea being colourful, after purification is used as a natural colouring agent or natural dye in various food industries. Being a traditional medicinal herb Clitoria ternatea is the only species among the Fabaceae family that is bestowed with the presence of cyclotides. Highest concentrations of cyclotides are found to be present in the roots of Clitoria ternatea. These cyclotides greatly possess antibacterial and immune stimulating activities ${ }^{12}$. The seeds of Clitoria ternatea also yielded lectin that agglutinates trypsin-treated human B erythrocytes. Among the various parts of the plant extracts, the extract of the seed has an effective larvicidal activity.

*Author for correspondence 
Silver Nano particles can also be synthesised from the extract of Clitoria ternatea. The seed extract of Clitoria ternatea is also used for the isolation of protein named 'finotin' that has enhanced antimicrobial and insecticidal activities? .

Clitoria ternatea being a medicinal plant has tremendous therapeutic compounds and hence occupies an important place in pharmaceutical industry. The plant is used to cure numerous diseases both in Ayurveda and traditional medicines. Various parts of the plant has numerous medicinal functions. The flower extract of the plant act as a good antiinflammatory, analgesics and also as antidiabetic agent. The leaf extract of the plants helps in preventing neurodegenerative diseases, diabetes mellitus and also controls excessive sweating. The root extract of the plant has good antioxidant activity and its bark is used as a diuretic and laxative. For irritation in bladder and urethra its decoction is used as a demulcent. The seed extract of the plant is used in swollen joints, abdominal viscera enlargement and dropsy. For centuries the extract of the plant has been used as a memory enhancer, antidepressant, stress reducer, anoxiolytic, sedative and tranquillizing agent ${ }^{2}$. The extract of the whole plant is used in treating sexual ailments such as gonorrhoea and infertility.

Clitoria ternatea has enhanced anxiolytic activities, anti- inflammatory and analgesic activities, antimicrobial activity, anticarcinogenic activity, nephroprotective activities, antistress activities. Its effect on general behaviour includes larvicidal activities, proteolytic activities, antihelmintic activities and antihyperglycemic activities. It has good antioxidant and antihistaminic profile making the plant more important in cancer treatment.

\section{Methodology}

\subsection{Collection of Plant}

Clitoria ternatea leaves were obtained from Sathya Mangalam forest. Using plastic bags, the leaves collected were transferred to lab. The powdered and sieved leaves of size $1 \mathrm{~mm}$ were finely powered and was stored in the Non-toxic-polyethylene bag.

\subsection{Plant Extract Preparation}

$10 \mathrm{gm}$ powder mass was extracted using $200 \mathrm{~mL}$ of methanol solvent. Dark maceration for 72 hours at $27^{\circ} \mathrm{C}$ was carried out and Whatman filter paper was used for filtration. The filtrate obtained was subjected to evaporation at $45^{\circ} \mathrm{C}$ and the residue was used for further analysis.

\subsection{Phytochemical Screening}

\subsubsection{Test for Alkaloids}

To $3 \mathrm{ml}$ of the extract $1 \mathrm{ml}$ of Mayer's reagent was poured and agitated well, presence of Alkaloids was indicated by the white precipitate at the bottom ${ }^{5}$.

\subsubsection{Test for Phlobatannin}

$10 \mathrm{ml}$ of aqueous extract of flower was boiled with $1 \% \mathrm{HCl}$. Presence of phlobatannin was indicated by the thick red precipitate deposition in the bottom ${ }^{5}$.

\subsubsection{Test for Triterpenoids}

$2 \mathrm{ml}$ of extract was added with 5 drops of concentrated sulphuric acid and kept undisturbed. Presence of triterpenoids was indicated by the appearance of greenish blue colour ${ }^{5}$.

\subsubsection{Test for Flavonoids}

The presence of flavonoids was identified by the use of alkaline reagent in the extract. Few drops of $10 \% \mathrm{NaOH}$ solution was added to $1 \mathrm{ml}$ of the extract and flavonoids was indicated by intense yellow colour, which disappeared on addition of a few drops of dilute $\operatorname{acid}^{5}$.

\subsubsection{Test for Lipids}

$0.5 \mathrm{~N}$ alcoholic potassium hydroxide was added along with a drop of phenolphthalein to $10 \mathrm{ml}$ of the extract. The mixtures were incubated on water bath for 1 hour. The presence of lipids was indicated by the formation of foam or soapy layer ${ }^{5}$.

\subsubsection{Test for Steroids}

$2 \mathrm{ml}$ of chloroform was added to extract and few drops of concentrated $\mathrm{H}_{2} \mathrm{SO}_{4}$. The presence of steroids was 
indicated by the appearance of red colour in the upper layer while yellow with greenish fluorescence appears in the $\mathrm{H}_{2} \mathrm{SO}_{4}$ layer ${ }^{5}$.

\subsubsection{Test for Terpenoids}

To $1 \mathrm{ml}$ of the aqueous extract $1 \mathrm{ml}$ of chloroform was added, mixed well and left for 5 minutes, $1 \mathrm{ml}$ concentrated $\mathrm{H}_{2} \mathrm{SO}_{4}$ was added after 5 minutes. The presence of terpenoids was indicated by the appearance of greyish layer ${ }^{5}$.

\subsubsection{Test for Tannin}

Braemer's test was used to indicate the presence of tannin. To $1 \mathrm{ml}$ of the extract, $2 \mathrm{ml}$ of water was added, boiled and filtered. Few drops of 5\% ferric chloride was added to the filtrate. The presence of tannin was indicated by a dark green, blue or brown colour ${ }^{5}$.

\subsubsection{Test for Glycosides}

To $0.5 \mathrm{ml}$ of methanol extract $1 \mathrm{ml}$ of glacial acetic acid with a trace amount of ferric chloride was added followed by $1 \mathrm{ml}$ of conc. sulphuric acid. The presence of glycoside was indicated by the formation of reddishbrown colour ring at the junction of 2-layers, upper layer turned in to bluish green colour ${ }^{5}$.

\section{Structural/Compound Estimation of Clitoria ternatea}

\subsection{GC-MS}

The sample was subjected to GC-MS evaluation to quantify the number of molecules and its structures. The analysis was performed using GCMS (Perkin Elmer model: Clarus 680) with mass spectrometer (Clarus six hundred(EI) analysed by (TurboMassver5.4.2) software program. The Clarus 680 GC employed a fused silica column, filled with Elite-5MS (5\% biphenyl $95 \%$ dimethylpolysiloxane, $30 \mathrm{~m} \times$ zero. $25 \mathrm{~mm}$ ID $\times$ $250 \mu \mathrm{m} \mathrm{df}$ ) and the components were separated using Helium as carrier gas at a constant drift of $1 \mathrm{ml} / \mathrm{min}$. The injector temperature was set at $260^{\circ} \mathrm{C}$ throughout the chromatographic run.The $1 \mu \mathrm{L}$ of extract was injected into the device, the oven temperature was set in the following sequence; $60^{\circ} \mathrm{C}(2 \mathrm{~min})$; followed by $300{ }^{\circ} \mathrm{C}$ at $10{ }^{\circ} \mathrm{C} \mathrm{min}-1$; and $300{ }^{\circ} \mathrm{C}$ for 6 min. The mass detector had transfer line temperature at $240{ }^{\circ} \mathrm{C}$; ion source temperature $240{ }^{\circ} \mathrm{C}$; and ionization mode electron impact at $70 \mathrm{eV}$, a test time of $0.2 \mathrm{sec}$ and test interval of $0.1 \mathrm{sec}$. The fragments analysed were ranging from 40 to $600 \mathrm{Da}$. The spectrums of the components were compared with the database of spectrum in GCMS NIST (2008) library.

\subsection{FT-IR}

A pellet was prepared by adding potassium bromide $(\mathrm{KBr})$ with a small quantity of $C$. ternatea methanol leaves extract. Using Thermo Electron Scientific FTIR spectroscope the pellet was subjected to analysis. The characteristics peaks and their functional group was detected ${ }^{5}$.

\subsection{Antibacterial Assay}

\subsubsection{Agar Well Diffusion Method}

Agar well diffusion is used for analysing the antibacterial activity of the extract. The extract was tested against different bacterial strains such as Streptococcus agalactiae, Salmonella typhi, Staphylococcus aureus, Enterobacteraerogenes, Escherichia coli and Bacillus subtilis. Nutrient agar medium was used in plating for this assay. These different bacterial cultures were swabbed separately in each different plate. Four wells were made using well injector. Of these four wells, two wells are used as control and the other two wells are used as test. Ampicillin was used as positive control. The test 1 was $50 \%$ of the extract and test 2 was $100 \%$ leaf extract. After filling the wells, the plates are incubated at $37^{\circ} \mathrm{C}$ for 24 hours at optimal conditions. After incubation the zone of inhibition exhibited by the antibiotics and the two test concentrations were compared and analysed.

\subsection{Cytotoxic Assay}

\section{MTT Assay}

The sample was subjected to in vitro cytotoxicity test. The used medium from the HL60 cells was replaced with fresh medium. The triplicates of the test were added to the cells, incubated at $37^{\circ} \mathrm{C}$ for $18 \mathrm{hr}$. After incubation MTT $(1 \mathrm{mg} / \mathrm{ml})$ was introduced in the wells 
and incubated for $4 \mathrm{~h}$. DMSO was added in the wells after incubation and the absorbance was read at 570 $\mathrm{nm}$. Cytotoxicity and cell viability were calculated by the below mentioned formula,

Cytotoxicity $=[($ Control-Treated $) /$ Control $] \times 100$

Cell Viability $=($ Treated $/$ Control $) \times 100$

\section{Result and Discussion}

The chemical components present in the extract was studied using Gas Chromatography Mass Spectrometry analysis. The extract composition was identified based on their retention time. The phytoconstituents were identified as propanoic acid, 3-hydroxy-, methyl ester; pyrimidine-2,4,6(1h,3h,5h)-trione, 1-octadecyl; 1-octanamine, n-methyl-n-nitroso; 3-o-methyl-dglucose; 2-o-methyl-d-mannopyranosa; undecanoic acid; 4-fluoro-1-methyl-5-carboxylic acid, ethyl(ester); nonadecanoic acid and neopentane-1,1-diol diacetate at various retention time of $14.698,14.838,14.998,19.82$,
20.07, 21.446, 22.761, 22.901 and 23.422 respectively. Most of the compounds identified belong to the esters and carboxylic acid family and are tabulated in Table 1.

Well diffusion method was performed to study the antibacterial activity of Clitoria ternatea extract. The macerated methanol leaf extract of Clitoria ternatea was studied for its antibacterial activity by the determination of zone of inhibition. The methanol leaf extracts were tested against Streptococcus agalactiae, Salmonella typhi, Staphylococcus aureus, Enterobacteraerogenes, Escherichia coli and Bacillus subtilis. The antibacterial effect of the extract against different bacterial species showed promising results and is tabulated in Table 2. The result of the study suggested that the extract showed greater resistance to Salmonella typhi and can be used to treat diseases caused by Salmonella typhi.

Phytochemical screening of Clitoria ternatea flower extract showed the presence of flavonoids, alkaloids, steroids, lipids, terpenoids, triterpenoids, phlobatannin, tannin and glycosides (Table 3).

Table 1. GC-MS analysis of methanol extract of Clitoria ternatea leaves

\begin{tabular}{|c|c|c|c|c|c|c|}
\hline S. No & Retention Time & $\begin{array}{l}\text { Compound } \\
\text { Name }\end{array}$ & $\begin{array}{l}\text { Molecular } \\
\text { Formula }\end{array}$ & $\begin{array}{c}\text { Molecular } \\
\text { Weight }\end{array}$ & Peak Area & Structure \\
\hline 1 & 14.698 & $\begin{array}{c}\text { propanoic acid, } \\
\text { 3-hydroxy-, } \\
\text { methyl ester }\end{array}$ & $\mathrm{C}_{4} \mathrm{H}_{8} \mathrm{O}_{3}$ & 104 & 7.146 & \\
\hline 2 & 14.838 & $\begin{array}{c}\text { pyrimidine- } \\
2,4,6(1 \mathrm{~h}, 3 \mathrm{~h}, 5 \mathrm{~h})- \\
\text { trione, } \\
1 \text {-octadecyl }\end{array}$ & $\mathrm{C}_{22} \mathrm{H}_{40} \mathrm{O}_{3} \mathrm{~N}_{2}$ & 380 & 3.133 & \\
\hline 3 & 14.998 & $\begin{array}{l}\text { 1-octanamine, } \\
\text { n-methyl-n- } \\
\text { nitroson }\end{array}$ & $\mathrm{C}_{9} \mathrm{H}_{20} \mathrm{ON}_{2}$ & 172 & 2.545 & \\
\hline 4 & 19.82 & $\begin{array}{l}\text { 3-o-methyl-d- } \\
\text { glucose }\end{array}$ & $\mathrm{C}_{7} \mathrm{H}_{14} \mathrm{O}_{6}$ & 194 & 25.732 & \\
\hline
\end{tabular}




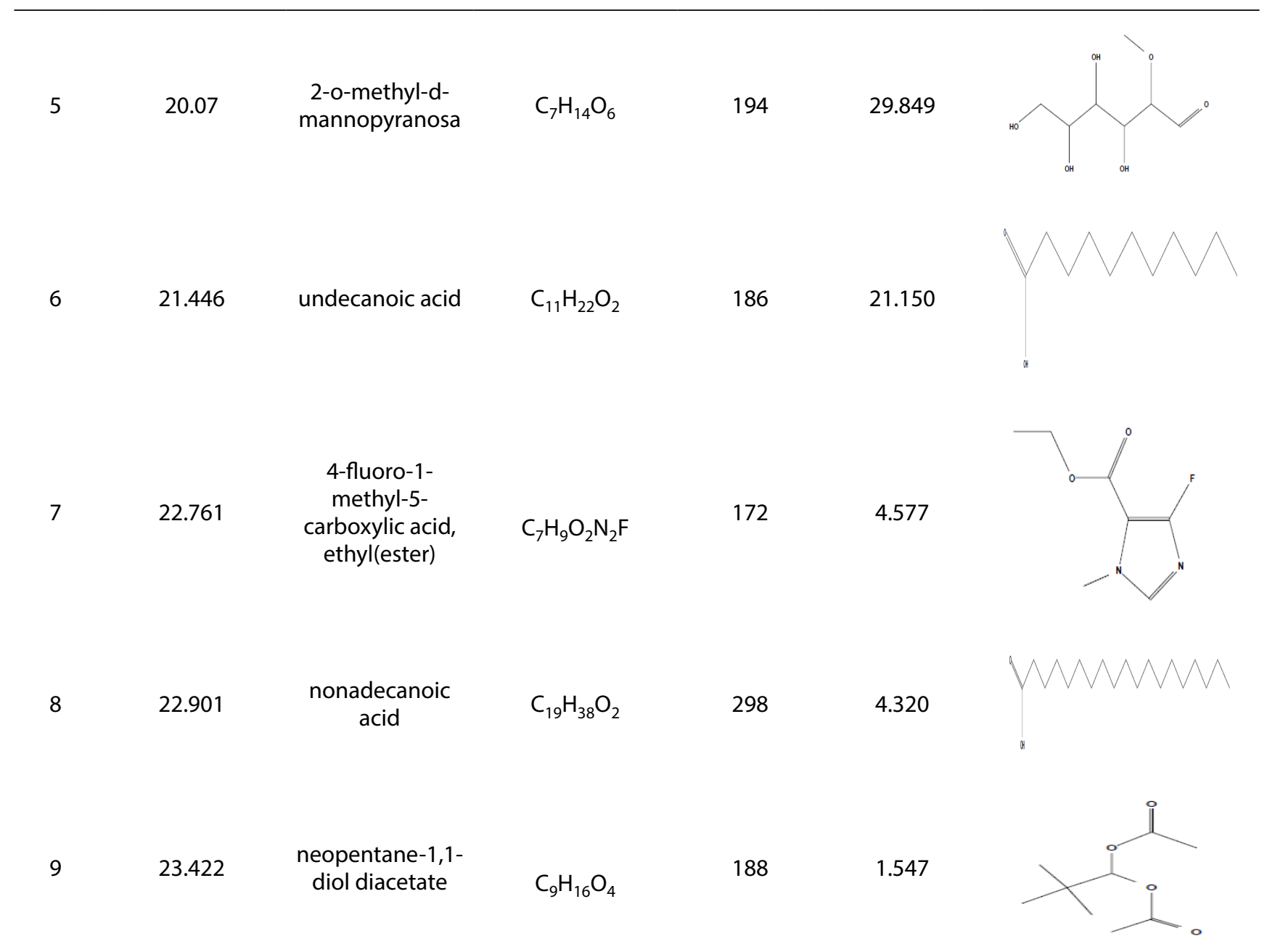

Table 2. Inhibition zone of methanol extract of Clitoria ternatea

\begin{tabular}{lcc} 
Microorganism & $\begin{array}{c}\text { Inhibition } \\
\text { Zone In } \\
\text { Extracts } \\
\text { (mm) }\end{array}$ & $\begin{array}{c}\text { Inhibition } \\
\text { Zone In } \\
\text { Ampicillin } \\
\text { (mm) }\end{array}$ \\
\hline Streptococcus agalactiae & 7 & 8.1 \\
Salmonella typhi & 9 & 13 \\
Staphylococcus aureus & 8 & 9 \\
Enterobacteraerogenes & 5.8 & 7.5 \\
Escherichia coli & 6.5 & 8 \\
Bacillus subtilis & 7.5 & 8.3 \\
\hline
\end{tabular}

The functional groups present in the leaf extract of Clitoria ternatea was observed under FTIR Spectroscopy. From the results obtained a graph was plotted between transmittance (\%) and wavenumber(1/ $\mathrm{cm})$. the functional group corresponding to each peak is tabulated in Table 4 and the graph in Figure 1.
Table 3. Chemical constituents of Clitoria ternatea leaf extract

\begin{tabular}{cc}
\hline Phytochemical constituents & Present/Absent \\
\hline Alkaloids & Present \\
Phlobatannins & Present \\
Triterpenoids & Present \\
Flavonoids & Present \\
Lipids & Present \\
Steroids & Present \\
Terpenoids & Present \\
Tannin & Present \\
Glycosides & Present
\end{tabular}

The MTT assay showed slight to severe cytotoxic reactivity to HL60 cells. Triplicates of the samples were done and analysed. The cell death increased with an increase in the concentration of the extract (Table 5). SEM analysis is shown in Figure 2. 


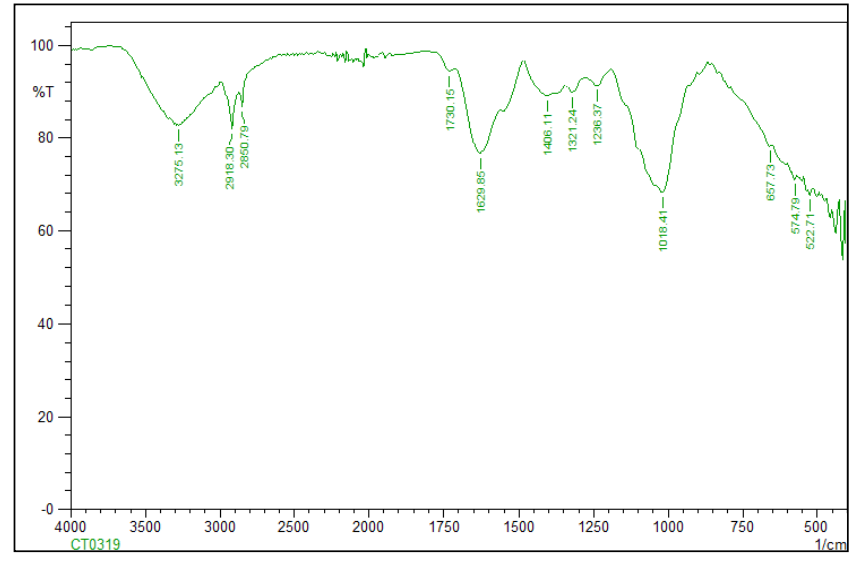

Figure 1. Transmittance $\%$ vs Wavenumber $(1 / \mathrm{cm})$ for the extract of Clitoria ternatea.

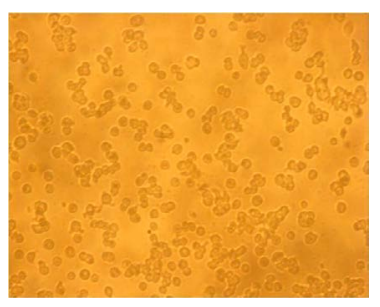

$100 \mu \mathrm{l}$

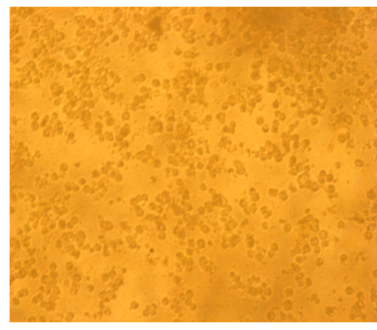

$25 \mu \mathrm{l}$

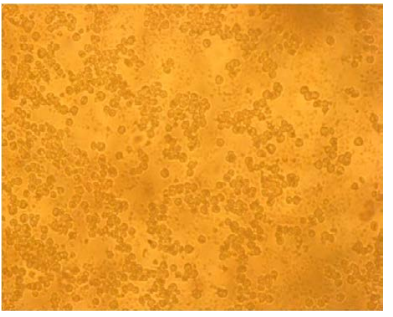

$50 \mu \mathrm{l}$

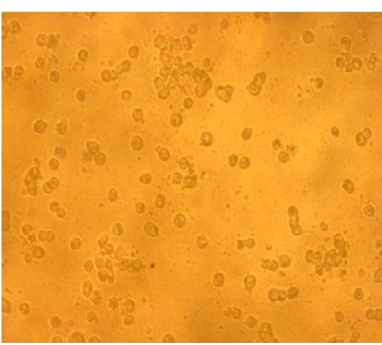

$250 \mu \mathrm{l}$
Figure 2. HL60 cells reactions at different sample concentrations.

\section{Conclusion}

This study gives us evidence about the bioactive compounds present in Clitoria ternatea. Extract was analysed and found to be rich in esters and carboxylic acid. The phytochemical secondary metabolites identified in this extract are flavonoids, alkaloids, steroids, lipids, terpenoids, triterpenoids, phlobatannin, tannin and glycosides. The antibacterial assay proved that the extract showed an accountable resistance to
Table 4. FTIR peak value corresponding functional group in methanol leaf extract

\begin{tabular}{|c|c|}
\hline Wave number $(1 / \mathrm{cm})$ & Functional Group/Assignment \\
\hline 3275.13 & Normal polymeric OH stretch \\
\hline 2918.30 & $\begin{array}{c}\text { Methylene } \mathrm{C}-\mathrm{H} \text { asymmetric/ } \\
\text { symmetric } \mathrm{C}-\mathrm{H}\end{array}$ \\
\hline 2850.79 & $\begin{array}{c}\text { Methylene } \mathrm{C}-\mathrm{H} \text { asymmetric/ } \\
\text { symmetric } \mathrm{C}-\mathrm{H}\end{array}$ \\
\hline 1730.15 & Aldehyde \\
\hline 1629.85 & Organic nitrates \\
\hline 1406.11 & Organic sulfates \\
\hline 1321.24 & Aromatic nitro compounds \\
\hline 1236.37 & Aromatic ethers, aryl O stretch \\
\hline 1018.41 & Cyclohexane ring vibrations \\
\hline 657.73 & Thioesters $/ \mathrm{CH}_{2}-\mathrm{S}$-/C-S stretch \\
\hline 574.79 & $\begin{array}{l}\text { Aliphatic iodo compounds, C-I } \\
\text { stretch }\end{array}$ \\
\hline 522.71 & $\begin{array}{l}\text { Aliphatic iodo compounds, C-I } \\
\text { stretch }\end{array}$ \\
\hline
\end{tabular}

Table 5. Cytotoxic activity of Clitoria ternatea leaf extract

\begin{tabular}{ccc}
\hline $\begin{array}{c}\text { Concentration }(\boldsymbol{\mu g} / \\
\mathbf{m l})- \text { CT0319-HL60 }\end{array}$ & $\begin{array}{c}\text { Cytotoxicity } \\
(\%)\end{array}$ & $\begin{array}{c}\text { Cell Viability } \\
(\%)\end{array}$ \\
\hline 250 & 79.93 & 20.07 \\
100 & 69.48 & 30.52 \\
50 & 54.36 & 45.64 \\
25 & 43.91 & 56.09 \\
12.5 & 39.03 & 61.97 \\
6.25 & 12.11 & 87.89 \\
3.125 & 5.81 & 94.18 \\
1.562 & 6.58 & 93.42 \\
0.781 & 5.49 & 94.50 \\
\hline
\end{tabular}

Salmonella typhi. Also, the extract showed anticancer activity against HL60 cells. Thus, from this study it can be concluded Clitoria ternatea leaves methanol extract has bioactive compounds showing anticancer activity against HL60 cells. 


\section{References}

1. Balaji KS, Priyanka S, Preethi SD, Chandrashekara KT, Lokesh S. Angio-suppressive effect of Clitoria ternatea flower extracts is mediated by HIF-1 $\alpha$ and down-regulation of VEGF in Murine carcinoma model. Medicinal Chemistry (Los Angeles). 2016; 6:515-20. https://doi.org/10.4172/21610444.1000392

2. Chakraborthy GS, Kumar V, Gupta S, Kumar A, Gautam N, Kumari L. Phytochemical and pharmacological aspects of Clitoria ternatea-a review. Journal of Applied Pharmaceutical Sciences and Research. 2018:3-9. https://doi.org/10.31069/ japsr.v1i2.13061

3. Deepika S, Selvaraj I, Anbalagan M. Phytochemical characterization and cancer cell line cytotoxicity of Clitoria ternatea. Bangladesh Journal of Pharmacology. 2018; 13(4):349-52. https://doi.org/10.3329/bjp.v13i4.38612

4. Divya A, Anbumalarmathi J, Sharmili SA. Phytochemical analysis, antimicrobial and antioxidant activity of Clitoria ternatea blue and white flowered leaves. Advances in Research. 2018:1-13. https://doi.org/10.9734/AIR/2018/39030

5. Lakshmi NDM, Mahitha B, Madhavi T, Sushma NJ. Phytochemical screening and ftir analysis of Clitoria ternatea leaves. International Journal of Scientific and Engineering Research. 2015; 6(2):287-90.

6. Jacob L, Latha MS. Anticancer activity of Clitoria ternatea Linn. against Dalton's lymphoma. International Journal of Pharmacognosy and Phytochemical Research. 2012; 4(4):207-12.

7. Jamil N, Zairi MNM, Nasim NAIM, Paee F. Influences of environmental conditions to phytoconstituents in Clitoria ternatea (Butterfly Pea Flower)-A Review. Journal of Science and Technology. 2018; 10(2).

8. Kamilla L, Mansor SM, Ramanathan S, Sasidharan S. Effects of Clitoria ternatea leaf extract on growth and morphogenesis of Aspergillus niger. Microscopy and Microanalysis. 2009; 15(4):366-72. https://doi.org/10.1017/S1431927609090783. PMid:19575837

9. Kumar D, Dhobi M. Antianxiety and antioxidant profile of blue and white variety of Clitoria ternatea L. Indian Journal of Research in Pharmacy and Biotechnology. 2016; 4(3):90.

10. Lijon MB, Meghla NS, Jahedi E, Rahman MA, Hossain I. Phytochemistry and pharmacological activities of Clitoria ternatea. International Journal of Natural and Social Sciences. 2017; 4(1):1-10.

11. Mathew N, Anitha MG, Bala TSL, Sivakumar SM, Narmadha R, Kalyanasundaram M. Larvicidal activity of Saracaindica, Nyctanthesarbor-tristis, and Clitoria ternatea extracts against three mosquito vector species. Parasitology Research. 2009; 104(5):1017-25. https://doi.org/10.1007/s00436-008-1284-x. PMid:19039604

12. Nguyen KNT, Nguyen GKT, Nguyen PQT, Ang KH, Dedon PC, Tam JP. Immunostimulating and Gram-negative-specific antibacterial cyclotides from the butterfly pea (Clitoria ternatea). The FEBS Journal. 2016; 283(11):2067-90. https:// doi.org/10.1111/febs.13720. PMid:27007913

13. Pasukamonset P, Kwon O, Adisakwattana S. Alginatebased encapsulation of polyphenols from Clitoria ternatea petal flower extract enhances stability and biological activity under simulated gastrointestinal conditions. Food Hydrocolloids. 2016; 61:772-9. https://doi.org/10.1016/j. foodhyd.2016.06.039

14. Kumar TR, Kumar S, Anju VS. Phytochemical and antibacterial activities of crude leaf and root extracts of Clitoria ternatea varieties (Fabaceae). Journal of Pharmacognosy and Phytochemistry. 2017; 6(6):1104-8.

15. Sarumathy K, Rajan MD, Vijay T, Jayakanthi J. Evaluation of phytoconstituents, nephro-protective and antioxidant activities of Clitoria ternatea. Journal of Applied Pharmaceutical Science. 2011; 1(5):164-72. 